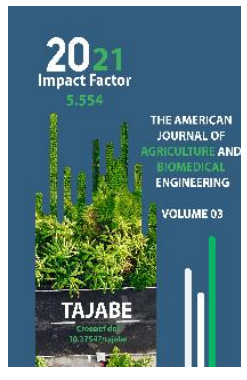

Journal Website: https://theamericanjou rnals.com/index.php/ta jabe

Copyright: Original content from this work may be used under the terms of the creative commons attributes 4.0 licence.

\section{Winter Resistance Of Winter Wheat Under Extreme Conditions}

\author{
Esbosyn Polatovich Sadykov \\ Candidate Of Agricultural Sciences, Senior Lecturer Of The Department, Nukus Branch Of The \\ Tashkent State, Agrarian University, Uzbekistan
}

Biisenbai Aripovich Bekbanov

Candidate Of Agricultural Sciences, Noun Employee, Karakalpak Scientific Research Institute Of Agriculture, Uzbekistan

Bibinaz Muratbaevna Kosbergenova

Doctoral Student, Tashkent State Agrarian University, Uzbekistan

Raikhan Mukhammedovna Aimuratova

2-Year Master's Student, Nukus Branch Of The Tashkent State, Agrarian University, Uzbekistan, Republic Of Karakalpakstan, Nukus City

\title{
ABSTRACT
}

The article discusses the issue of frost resistance of varieties and samples of winter wheat sown at different depths, in the extreme conditions of Karakalpakstan. Both a decrease and an excessive deepening of sowing leads to a significant decrease in their resistance to low temperatures, which negatively affects their subsequent survival in the spring-summer period. On the basis of the data, 2 varieties were selected, they turned out to be frost-resistant and differed in good yield and other valuable traits in comparison with the zoned varieties. They were transferred to the State Commission for Variety Testing of Agricultural Crops, under the name "Chimbay" and "Aral".

\section{KEYWORDS}

Cultivar, specimen, plastic cultivars, frost resistance, survival, continental climate, extreme conditions, hardening, temperature fluctuations, soil salinity.

\section{INTRODUCTION}

Due to the increasing drying up of the Aral Sea, in its southern zones, the degree of soil salinity, climate dryness and moisture deficit have increased in recent years. Therefore, in these extreme conditions, the study and testing of breeding materials, the creation of new donors and wheat varieties is relevant. Therefore, purposeful breeding work is necessary to breed winter-hardy, heat-resistant and diseaseresistant varieties of winter wheat. The creation of frost-resistant varieties for the Republic of Karakalpakstan, not only increases 
the overall grain production, but also improves the quality of products.

\section{MAIN PART}

Frequent sharp cold snaps, instability of the temperature regime of the winter period with little or no snow cover, autumn droughts preceding overwintering, cause serious damage to winter wheat crops, and even their death in large areas. Therefore, testing and isolating frost-resistant varieties and forms, as well as the development of effective methods to prevent the death of winter wheat, remains one of the urgent tasks.

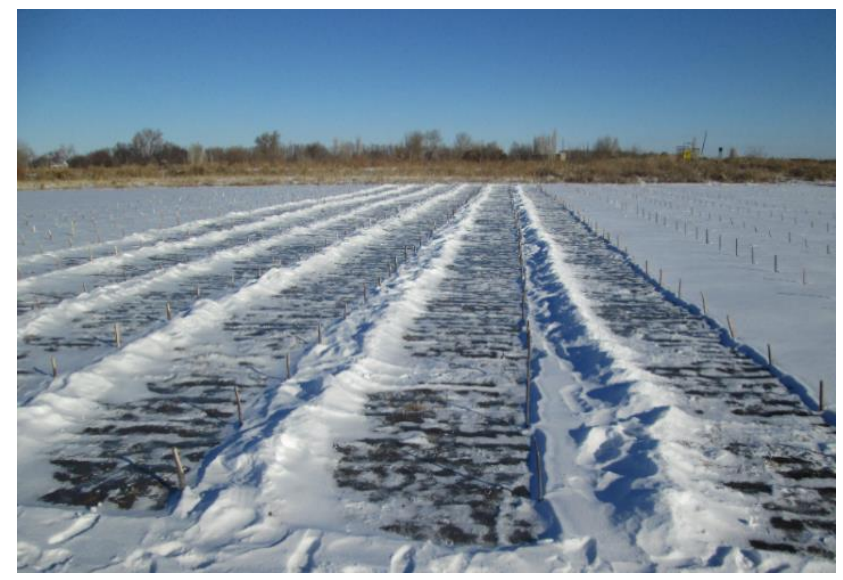

A feature of frost-resistant varieties is their great plasticity, which makes it possible to form and maintain high frost resistance for a longer period of time, with a deviation from the optimal sowing time. Comparatively more plastic varieties with optimal sowing dates, less reduce frost resistance and yield.

The resistance of plants to low temperatures is formed, as a rule, when sowing at the optimum time. Powerfully developed, overgrown plants of early sowing terms have a weak frost resistance. Late-term plants, which go into winter without having time to bloom, with an underdeveloped root system and a small supply of plastic substances, also have a reduced frost resistance, although their death often occurs at lower temperatures than plants of early sowing terms.

Winter wheat cultivated in the Republic of Karakalpakstan is highly susceptible to the influence of various kinds of unfavorable environmental factors. This is one of the reasons for their low and unstable yields and gross grain yields. Among the unfavorable environmental factors, the greatest negative impact on the productivity and quality of the resulting crop is exerted by winter cold, late spring and early autumn frosts, air and soil drought, high concentration of salts in the soil, etc.

The power of the vegetative mass of plants has unequal potential for the accumulation of a sufficient amount of protective substances in the tillering nodes, the vital activity of which determines the resistance of winter wheat to unfavorable wintering conditions.

The harm caused by unfavorable environmental factors can be reduced by organizing targeted selection, as well as further improving cultivation techniques. The group of cultivation measures includes, first of all, a scientifically grounded choice of sowing dates, a fertilizer system and the use of physiologically active substances. As for the creation of resistant varieties, it becomes a reality after the development of appropriate objective methods for assessing and identifying resistant forms with their subsequent use in production practice. As you 
The American Journal of Agriculture and Boimedical Engineering

(ISSN - 2689-1018)

IMPACT FACTOR

Published: July 14, 2021| Pages: 1-10

Doi: https://doi.org/10.37547/tajabe/Volume03Issue07-01

2021: 5.554

OCLC - 1121105746

know, an important reserve for intensive land use is the introduction of highly productive varieties.

In the formation of the properties of frost and winter hardiness of winter crops, great importance is attached to the process of accumulation and consumption of sugars. It has been established that the ability of winter plants to develop high frost resistance depends, first of all, on the growing conditions in autumn and on the biological characteristics of the variety. When receiving timely shoots, the differences created by the sowing time and expressed in the duration of the autumn growing season and the sum of the average daily temperatures, affect the vigor of the plants.

According to some authors [1]: for various varieties of winter wheat, they require the necessary conditions for the formation of their high frost resistance and productivity.

Increasing the stability of the yield of grain and other valuable traits in different years should become one of the main tasks of the breeding improvement of this crop. The death of winter crops most often occurs from low temperatures with insufficient or complete absence of snow on crops. In conditions when crops are directly affected by low temperatures, the high frost resistance of varieties is of decisive importance.

Plants of late sowing periods have a weak winter hardiness, which go into winter without having time to bloom, poorly rooted, with a small supply of plastic substances. Plants of too early sowing terms are also characterized by reduced frost resistance and winter hardiness.
Internal changes in early-term plants inevitably lead to a decrease in their winter hardiness. Due to the reduced winter hardiness of such plants, the aboveground mass formed in them dies off during the wintering period, often by $60-70 \%$ or more. Thus, in order to obtain winterhardy, highly productive plants and grow a high yield, it is necessary to observe scientifically grounded optimal sowing times for each variety [2, 42-48]

There are no universal varieties for all zones, that certain varieties require conditions corresponding to their biological characteristics. Therefore, in different climatic zones, due to varietal characteristics, the biology of the variety, meteorological factors, and other physiological processes may accelerate or slow down. [3]

Choosing the right variety for the locality and for the desired use of the grain is paramount to the success of the crop. Since the varieties have different properties, there is always a difference between them in terms of yield, suitability for local conditions, as well as in response to stress factors [4]

Varieties of local origin, such as two-handed, differs from varieties of other ecological groups in enzymatic activity, greater plasticity, wide adaptive amplitude, water retention force during critical periods, intensive assimilation, as well as high drought and frost resistance [5]

In breeding samples obtained from crossing genotypes specific for winter hardiness, the degree of expression of the trait mainly deviates towards the best parent. Crossing with samples from areas with other ecological 
conditions gives good results, in particular, they allow to obtain transgressive forms. Usually varieties of local selection are used as maternal forms [6]

Varieties with wide ecological plasticity, do not react so sharply to unfavorable external conditions, and provide a more stable yield over the years. Therefore, the main direction of selective seed-growing work with wheat is to create varieties that combine high productivity with good grain quality, as well as high environmental plasticity. [7]

The success of overwintering depends on the condition of the plants before going into winter (height, bushiness, weight), on the conditions of hardening and the weather. Temperature fluctuations during the hardening period adversely affect the preparation of plants for winter and cause their death during overwintering. Under optimal conditions for preparing winter wheat for overwintering, the plants leave well-hardened in winter, and their death is minimal.

The process of dying off of plants takes place in separate interphase periods of growth and development, not with the same intensity. Plants damaged but not dead in winter, with the resumption of vegetation in spring, restore and form new leaves.

Some researchers argue that any culture, even those not related to the number of frostresistant ones, carries an undiscovered potential for resistance.

In the autumn growing season, the readiness of plants to endure unfavorable wintering conditions and to form a crop in the spring and summer is determined. Along with the temperature, age-related changes also have a noticeable effect on the state of plants by the time the autumn vegetation ends, which are not the same in plants by this calendar date. This is natural, since during the period of the autumn growing season, plants reach various stages of development. If some plants barely have time to open up and have only rudiments of nodal roots, then some by this time form a powerful aboveground part with welldeveloped nodal roots and they form high productivity.

To increase the frost resistance of winter wheat in the autumn period, a sufficient mineral nutrition, both in terms of quantity and balance of elements, is required, which excludes overgrowth of plants. The lack of one or several elements in the composition of the fertilizer, as well as their excess, lead to a decrease in the resistance of winter crops to negative temperatures.

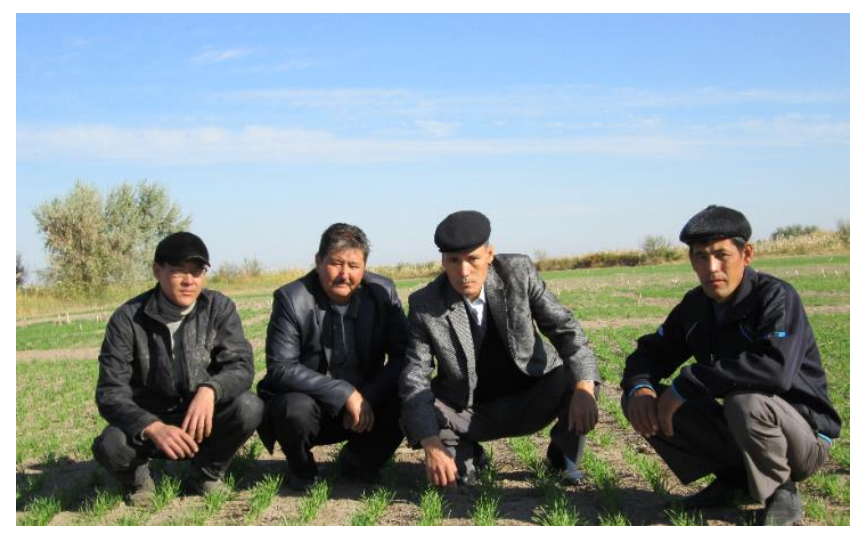

The optimal sowing time and sowing depth, under normal temperature conditions, good moisture supply, form a more powerful aboveground mass and root system than later dates. Plants sown to a depth of $4 \mathrm{~cm}$ or more have the highest winter hardiness, this can be 
The American Journal of Agriculture and Boimedical Engineering (ISSN - 2689-1018)

seen from the data in Table 1. A decrease or excessive deepening of sowing leads to a significant decrease in their resistance to low temperatures, which negatively affects their subsequent survival in spring and summer. period. Favorable conditions created in the spring period do not smooth out the differences that appeared in winter plants in the initial phases of development in the fall.
They persist until the end of the growing season and ultimately affect their productivity.

Winter 2017-2018 differed in less precipitation. So, in January there was a slight sediment (10.5 $\mathrm{mm}$ ), this is not enough to cover the soil surface. The winter was mild. Thus, the average monthly temperature in December was -3.10 , and in January-February, respectively. -3.0; 0.90 .

Table 1

Frost resistance of varieties and samples of winter wheat when sown at different depths

\begin{tabular}{|c|c|c|c|c|c|}
\hline \multirow[t]{2}{*}{ № } & \multirow[t]{2}{*}{$\begin{array}{c}\text { Name of variety and } \\
\text { specimen }\end{array}$} & \multicolumn{2}{|c|}{$\begin{array}{l}\text { When sowing at depth } \\
\qquad 4 \text { SM. }\end{array}$} & \multicolumn{2}{|c|}{$\begin{array}{c}\text { When sowing at } \\
\text { depth } \\
2 \mathrm{sm}\end{array}$} \\
\hline & & 2017 & 2018 & 2017 & 2018 \\
\hline 1 & 20 FAWWSA -216 & 91,1 & 93,0 & 88,0 & 84,0 \\
\hline 2 & 20 FAWWIR - 23 & 90.9 & 93,0 & 87.0 & 78,0 \\
\hline 3 & YONBJSH & 93,3 & 95,0 & 89,0 & 90,0 \\
\hline 4 & 13 AYTIR -9010 & 93,0 & 92,0 & 88,0 & 88,0 \\
\hline 5 & TANYA & 92,0 & 93.0 & 87,0 & 88,5 \\
\hline 6 & 16 IWWYTIR - 9831 & 93,0 & 89.0 & 87,0 & 77,0 \\
\hline 7 & 13 YTIR - 6074 & 92,0 & 94,0 & 87,0 & 86,0 \\
\hline 8 & 13 YTIR -6003 & 93,4 & 95.0 & 89,0 & 83,0 \\
\hline 9 & 13 YTIR -6153 & 90,6 & 95,0 & 87.0 & 83,0 \\
\hline
\end{tabular}


The American Journal of Agriculture and Boimedical Engineering

(ISSN - 2689-1018)

IMPACT FACTOR

Published: July 14, 2021| Pages: 1-10

Doi: https://doi.org/10.37547/tajabe/Volumeo3Issue07-01

2021: $5 \cdot 554$

OCLC - 1121105746

\begin{tabular}{|c|c|c|c|c|c|}
\hline 10 & 20 FAWWSA -283 & 93,0 & 93,0 & 88,0 & 81,0 \\
\hline 11 & SAHRAY & 93,8 & 93.0 & 87,0 & 80,0 \\
\hline 12 & 13 YTIR - 6165 & 92.8 & 94,0 & 88,0 & 83,0 \\
\hline 13 & 20 FAWWSA 216 & 91,1 & 94.0 & 88,0 & 84,0 \\
\hline 14 & KR 12-08 & 90,4 & 87,0 & 88,0 & 75,0 \\
\hline 15 & 20 FAWWIR - 144 & 92,4 & 84.0 & 88,0 & 85,0 \\
\hline 16 & 16 IWWYTIR - 9815 & 93,1 & 94,0 & 86,0 & 75,0 \\
\hline 17 & 15 IWWYTSA - 15 & 91,0 & 93,0 & 86,0 & 83,0 \\
\hline 18 & MOSKVICH & 93,0 & 92,0 & 87,0 & 82,0 \\
\hline 19 & KR 11-40 & 90,2 & 94,0 & 88,0 & 80,0 \\
\hline 20 & 20 FaWWSa -295 & 91,0 & 92,0 & 85,0 & 86,0 \\
\hline
\end{tabular}

In all varieties and accessions sown to a depth of $4 \mathrm{~cm}$, overwintered plants amounted to $100.0 \%$. But some samples differed from others as KR 12-18, 20 FAWWSA-278, 13 Ytir-6101, Bezostaya-1, 13 Aytir-9004, Yanbash showed good winter hardiness even with shallow sowing of seeds.

According to the data (Table 1), it can be seen that the varieties widely cultivated in production are more frost-resistant. Thus, the Krasnodarskaya-99 variety in terms of frost resistance occupies one of the first places in the northern soil-climatic zone of the republic.

An important quality of the variety is its plasticity, i.e. the ability to form properties such as frost resistance over a longer period of time. Frost-resistant varieties allow you to successfully maneuver winter frosts without damage. The data obtained show the same winter hardiness of the studied varieties and samples, depending on the sowing depth. The comparatively slower growth and development of plants in the autumn-winter period determines a higher winter hardiness. This explains the relatively high overall frost resistance in field conditions.

Preparation for wintering and the wintering itself in such winter wheat plants also take place differently. In less winter-hardy varieties of winter wheat, the state of dormancy occurs somewhat later than in winter-hardy varieties. Therefore, even at low temperatures in the second half of autumn, they accumulate plastic substances comparatively more intensively. The high resistance to low temperatures in varieties does not manifest itself in the same calendar period, depends, first of all, on the duration of the period of seedlings, the beginning of elongation of growth cones and on its state before going into winter.The duration of winter dormancy in different varieties of winter wheat is not the same. Regardless of the accumulated stock, by the end of the autumn growing season, it is crucial 
for the formation of frost resistance of plants. The depth of dormancy is the smallest in unstable winters with frequent thaws, especially in low-hardy varieties. In plants of such varieties, growth processes are comparatively more intensive in winter.

Varieties of optimal sowing dates have time to open up normally, take root, and only a small amount of the lower leaves of the main shoots dry out. Usually, in plants of such crops, vernalization ends by the time the autumn vegetation ends. Consequently, plants of different ages, i.e. differing in the degree of development of plants, before hibernation are at different levels of development. This, in turn, enhances or weakens the adaptation of the plant organism to the effects of unfavorable factors during wintering..

Less frost-resistant varieties lose a lot of aboveground mass during the wintering period. Due to damage by low temperatures, regeneration of the aboveground parts slowly proceeds in the spring. For the most favorable overwintering of winter crops, the temperature is considered to be slightly higher than $-100 C$. Well-hardened wheat tolerates short-term temperature drops down to -20, -

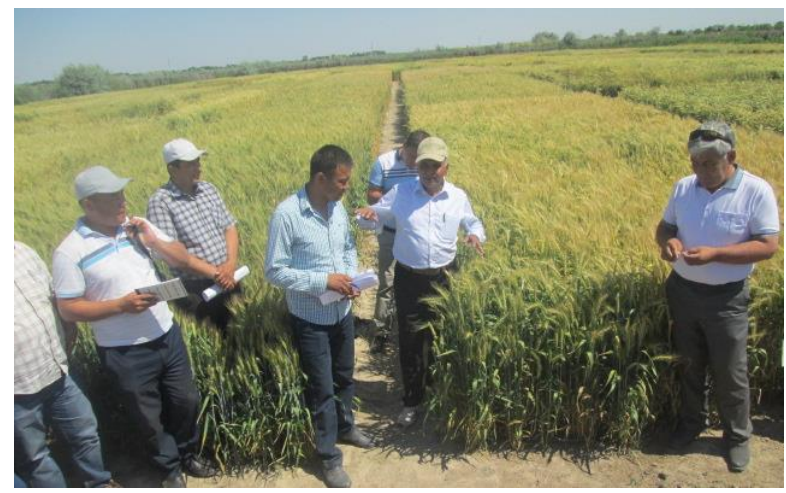

$220 \mathrm{C}$. With a snow cover $25-30 \mathrm{~cm}$ high, even with frost down to $-40 \mathrm{C}$, at the depth of the tillering node of winter wheat it does not fall below $-150 \mathrm{C}$.

The unequal plasticity of varieties depends on a number of biological characteristics of the variety, including the duration of the sprouting period. Sown varieties and samples with a longer duration of the autumn growing season are among the most plastic. Samples with maximum frost resistance, by the time they leave for winter, have on average 3-4 shoots, on the main of them 3-4 formed and normally vegetating leaves. Consequently, different varieties and specimens are at different levels of development before going into winter. This, in turn, enhances or weakens the adaptation of the plant organism to the effects of unfavorable factors during wintering.

In severely damaged plants, heading began much later than usual, in comparison with undamaged plants, degenerative ears with shrunken grain are formed in them. Summer death of winter crops depends mainly on damage by low temperatures during the wintering period and is aggravated by a lack of moisture in the spring and summer period.

Research materials, both zoned and promising varieties of winter wheat, as well as samples of different winter hardiness, were sown at different depths ( 2 and $4 \mathrm{~cm}$ ), at the optimal time. The conditions of the autumn period influenced the growth and development of plants in different ways. At the same time, their resistance to winter frost was taken into account.

The properties that determine the suitability of a variety for a given area are the main distinguishing feature of all varieties. The 
peculiarities of the variety for this property can be divided into two groups: with good adaptation to the external environment and special varieties, more narrowly specialized to specific areas. The varieties of the first group are distinguished by good ecological plasticity. They have a fairly good manifestation of properties to the negative influences of the external environment, the risk of growing is reduced, so they give good and relatively stable yields under different conditions.

The choice of a variety for a given location and for the desired use of the grain is of paramount importance to the success of the crop. Since varieties have different properties, there is always a difference between them in terms of yield, suitability for local conditions, quality and resistance to diseases and pests, as well as in response to stress factors.

Under unfavorable wintering conditions, there is a sparseness of crops during the springsummer growing season. In damaged plants, significant changes in the course of physiological processes are also noted, which have a negative effect on the onset of the next phases. Observation data on the development of winter wheat plants exposed to negative temperatures indicate a significant delay in the passage of phenological phases by them in comparison with undamaged ones.

The main reason for the lag in the growth and development of plants is damage to them by low temperatures, as a result of which the most valuable part of plants, the main stem, dies off. The lagging behind in the development of plants is the period of earingflowering. By the end of the growing season, it smoothes out somewhat, but does not completely disappear.

In specimens sown at a depth of $2 \mathrm{~cm}$, heading occurred 2-6 days later, in comparison with specimens at a depth of $4 \mathrm{~cm}$.For example, in specimens Tanya, 16 iwwyt-ir-9831, 16 Iwwyt-ir -9815, 20 FAWWSA -295, 20 FAWWSA-283, KR 11-29. 20 Fawwir - 30.20 Fawwir-152 b KR - 11-29 in 2017, heading began on April 20-25. The same samples, sown at a depth of $4 \mathrm{~cm}$, their heading phase began 6-8 days earlier. In 2018, for samples KR 12-09, 20 Fawwsa - 292, 13 Aytir - 9048, 20 Fawwir -139, 13 Aytir -9046, 20 Fawwir -152, 20 Fawwsa - 293 when sown at a depth of $2 \mathrm{~cm}$, the heading phase began 2-4 days later. Some varieties, such as 13 Aytir 6074, 13 Aytir -6003, 20 Fawwir -152, KR 12-18, 20 Fawwir -23 , did not differ in earing date, depending on the sowing depth, the same patterns were obtained with other varieties ... This is apparently due to the adaptation of varieties to growing conditions.

The developmental phases vary greatly depending on the duration of the action of various environmental factors and the biological characteristics of the variety itself. Not all varieties react in the same way to certain influences of external factors.

A feature of the agroclimatic conditions of the republic is the fairly observed dry frosts, which cause significant damage to winter wheat crops.

Varieties react differently to external conditions under the same growing background. Regardless of the differences in overwintering, the plants in the subsequent growing season, growth and development 
proceeded normally. There is a clear difference in the date of onset of ripeness between varieties and samples, depending on the depth of sowing of seeds. So, in 2017, in samples Kinagy-97, 20 FAWWiR-88, 20 Fawwsa -216, 20 Fawwsa -214, KR 12-18, 20 Fawwir -38, 20 Fawwir -152 when sowing seeds at a depth of 2 $\mathrm{cm}$, ripeness came 3-5 days later than the sown samples at a depth of $4 \mathrm{~cm}$. The same varieties were later when sown at a depth of 2 and $4 \mathrm{~cm}$, i.e. their ripeness came 4-6 days later, in comparison with similar samples. As you know, in years with low relative humidity and high air temperature, full ripeness occurs earlier than usual, since in such years the intensity of grain drying is fast.

In the north of the republic, damage and death of winter crops are most often caused by low temperatures with insufficient or complete absence of snow on crops. Winter wheat varieties differ in their resistance to negative temperatures. In conditions when crops are directly affected by low temperatures, the high frost resistance of varieties is of decisive importance. The ability of plants to develop high frost resistance depends primarily on the biological characteristics of the variety and the growing conditions of plants in the autumn growing season.

Varieties of optimal sowing dates have time to open up normally, take root, and only a small amount of the lower leaves of the main shoots dry out. Usually, vernalization ends in plants of such crops by the time the autumn vegetation ends. Consequently, plants of different ages, i.e. differing in the degree of development of plants, before hibernation are at different levels of development. This, in turn, enhances or weakens the adaptation of the plant organism to the effects of unfavorable factors during wintering.

An important quality of the variety is its plasticity, i.e. the ability to form properties such as frost resistance over a longer period of time. Frost-resistant varieties allow you to successfully maneuver winter frosts without damage.

Each newly zoned variety, as a rule, differs from the previously cultivated ones not only by increased yield, but also by better quality indicators. In breeding and seed-growing work, the leading characteristics are productivity and grain yield from the total biomass yield. This makes it possible to increase the collection of quality products per unit area. A certain influence is exerted on the productivity of plants by the mass of 1000 pcs. seeds and it characterizes varieties by grain size. As the data shows, all tested varieties and new accessions are large-seed varieties, because they all have a weight of 1000 pieces. grains above 40 grams.

One of the most important factors in solving the problem of growing grain of strong wheat is the creation of winter wheat varieties with a high amount and quality of the protein complex and capable of maintaining good quality indicators even under unfavorable growing conditions. Wheat varieties can only maintain high quality values under certain growing conditions. The decisive factor for the accumulation of protein substances in the grain is the growing conditions, primarily the weather conditions. Significant fluctuations in the protein content of grain are observed not only within the zone, but also in the same farm. The main reason for the variability in protein 
content is differences in soil fertility and agricultural technology.

\section{REFERENCES}

1. Климов А.Н. - Зимостойкость, выживаемость и продуктивность озимой пшеницы в зависимости от условий увлажнение почвы и температурного режима. Повышение продуктивности озимой пшеницы .Днепропетровск:1980. -16 с.

2. Бондаренко В.И. Влияние зимних повреждений на развитие и продуктивность растений озимой пшеницы.. Повышение продуктивности озимой пшеницы. Днепропетровск: 1980.- 56 c.

3. Мичурин И.В. Семена, их жизнь и хранение до посева. Избр. соч. М.: 1939.-86 c.

4. Гриб С.И. Семеноводство полевых культур. Минск.: «Ураджай», 1994.- 256 с.

5. Аманов М.А. Устойчивость пшеницы Узбекистана к неблагоприятным факторам среды. Изд., «ФАН», Ташкент, 1978. -48 c.

6. Коновалов Ю.Б. Частная селекция полевых культур. Москва, 1990.-302 с.

7. Бекбанов Б.А. Озимая пшеница в Южном Приаралье. //Сельское хозяйство Узбекистана, 2004/ №8.С.1518. 